\title{
Number of Unigenes
}

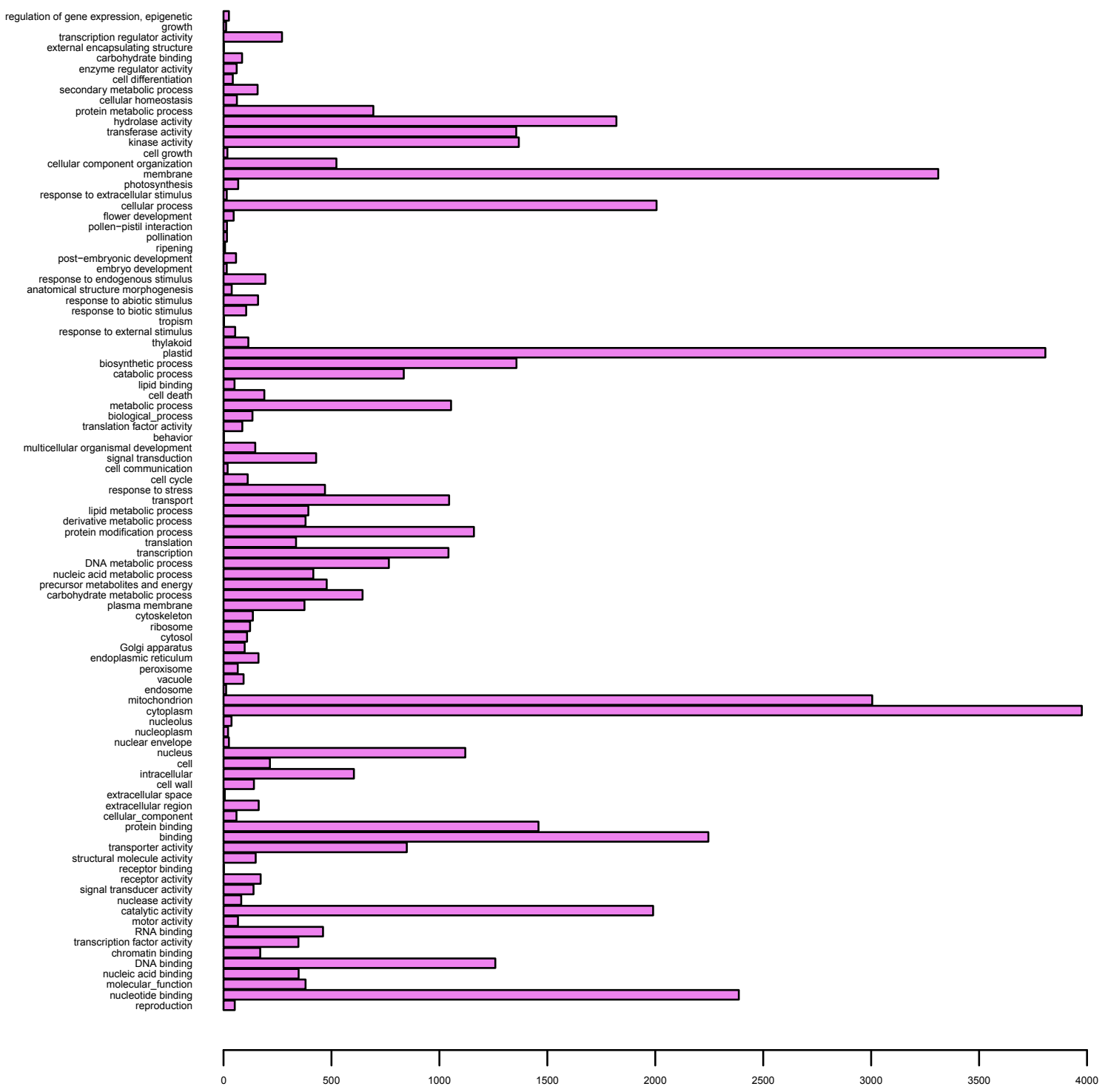

